\title{
Classical in/stabilities: Virginia Woolf, Ford Madox Ford, and the Great War
}

\author{
J. H. D. Scourfield*
}

Widely felt as a chasm in history, the First World War raised in an acute form profound questions concerning the relationship of the post-War present to the past. In the cultural renegotiation that ensued, the place not only of the classical past but of Classics itself as an element of that culture came under scrutiny. If, in the words of H.D., 'the old order was dead', and heroic models had failed, what value could still attach to Classics? Confronting this question, modernist writers in Britain and elsewhere proposed a variety of answers. In this article, I examine how Classics is represented and exploited in works by two major modernist authors which look back at and seek to articulate a response to the War: Virginia Woolf's Jacob's Room (1922) and Ford Madox Ford's Parade's End (1924-8). In both cases, I argue, Classics is at the same time associated with a world of outdated structures, values, and beliefs, and employed as an instrument of the cultural critique which enables that judgement. Thus renewed, and offering itself in these texts to constructive, forward-looking appropriations, Classics demonstrates an adaptive stability that to some in November 1918 might have seemed pure illusion.

I

What price Classics in November i9 I 8? The 'old Lie' had been exposed; 'the era of Victorian Hellenism' (to quote Christopher Stray) was about to receive 'its symbolic death blow' in the abolition of the compulsory Greek requirement at Cambridge, soon to be followed by Oxford $;^{2}$ and in some quarters there was a literal cost. In Berlin in I9I2, Ulrich von Wilamowitz-Moellendorff, the renowned Professor of Classical Philology at the Friedrich-Wilhelms-Universität, had taken on a South

* Correspondence: Maynooth University Department of Ancient Classics, Maynooth University, Maynooth, Co. Kildare, Ireland. david.scourfield@mu.ie

David Scourfield is Professor of Classics at Maynooth University (National University of Ireland Maynooth). He is currently working on a monograph on classical receptions in the work of E. M. Forster.

I Wilfred Owen, 'Dulce et decorum est', lines 2I-28: 'If you could hear, at every jolt, the blood | Come gargling from the froth-corrupted lungs, | Obscene as cancer, bitter as the cud | Of vile, incurable sores on innocent tongues, $-\mid$ My friend, you would not tell with such high zest | To children ardent for some desperate glory, | The old Lie: Dulce et decorum est | Pro patria mori [Hor. Carm. 3.2.I3]' (Owen I983: I. I40). Owen's citation of Horace in this poem is explored in detail by Angela Hobbs in this issue.

2 Stray (1998: 297); for fuller discussion of the 'compulsory Greek' issue, see Stray (I998: 265-9), Raphaely (I999). 
African doctoral student named Johannes Basson. ${ }^{3}$ Awarded his degree in I9I7, Basson returned home in the final weeks of the Great War to assume the Chair of Classics at his alma mater, the University of Stellenbosch. An Afrikaner nationalist - an identity nowhere better illustrated than in his doctoral 'Vita', where he identifies himself as 'Iohannes Basson, natione Boerus' ('Johannes Basson, by nationality a boer' $)^{4}$ — Basson had strong pro-German sympathies, and in July I920, together with another Stellenbosch graduate who had studied in Berlin and Zurich, the zoologist P. J. du Toit, published an appeal in the nationalist newspaper $D e$ Burger under the heading 'Die duitse wetenskap' ('German scholarship'). ${ }^{5}$ Basson and du Toit stated that in Germany the costs of basic scholarly materials and equipment had risen to the point where 'from their annual government grants many institutes cannot purchase even a single microscope', ${ }^{6}$ and that the Prussian State Library in Berlin, which in I9 I4 had taken 2,400 foreign learned journals, could now, six years later, support only I40: such was the impact of the War and the reparations demanded under the Treaty of Versailles. Conscious of a debt owed by Afrikaners such as themselves to German scholarship, they appealed to 'everyone who values the interests of our own higher education'7 to contribute to funds to be sent to the State Library for the purchase of foreign journals. The response far exceeded the expectations of Basson and du Toit. The notice in De Burger indicates that they hoped to collect $f_{5}$ o or $f_{1}$ Ioo, perhaps more. Ten weeks later Basson was able to send Wilamowitz the sum of $\AA_{325}$, with a request that he forward it to Adolf von Harnack, the great Church historian who was now Director-General of the State Library, for the purpose specified. ${ }^{8}$ Further contributions, totalling $f_{\mathrm{I}} \mathrm{O}_{5}$, followed over the next month. ${ }^{9}$ Especially striking is that Basson's letters to Wilamowitz reveal the chief donors to have been not educated Afrikaners but prominent South African businessmen and industrialists of German origin, politically inclined not towards Afrikaner nationalism but towards the more inclusive, unionist, side represented above all by Jan Smuts. ${ }^{\text {Io }}$

3 Helpful information on Basson may be found in Smuts (I966: 27-30). Most of what is said in the present article, however, is derived from unpublished material, namely the letters of Basson to his Doktorvater in the Wilamowitz Nachlass in Göttingen (Cod. Ms. Wilamowitz 53); I propose to publish all the letters in a future paper.

4 Basson (i9i7: 72).

5 De Burger, 29 July i920; I am reliant for this on the copy of the appeal notice accompanying the Basson letters in Cod. Ms. Wilamowitz 53 in Göttingen, at the top of which is printed 'Uit "De Burger" van Donderdag, 29 Julie I920'.

6 'menige instituut uit sy jaarlikse regeringstoelaë nie eens 'n enkele mikroskoop kan koop nie' (translations from the Afrikaans are my own).

7 'almal wat die belange van ons eie hoëre onderwys op prys stel'.

8 Basson, letter to Wilamowitz, 7 October I920; this letter also indicates that Basson expected to raise only about $£, 50$.

9 Basson, letters to Wilamowitz, 28 October and 4 November I920. 
This story is suggestive. In the first place, it illustrates the immediate and dramatic impact of the Great War on scholarly, and thus intellectual, life in a country previously at the forefront of international scholarship, not least in Classics. Basson's appeal was, of course, not at all partisan in a disciplinary sense, but his role in the enterprise, and particularly that of Wilamowitz, now 7 I and a Hellenist of unmatched international distinction, may serve as an emblem of the challenges that Classics faced at the beginning of the I920s. At the same time, the success of the appeal is testament not only to a sense of connection with the mother-country among German South Africans but also to the value they placed on scholarship and its traditions. In his letter of self-introduction to Wilamowitz in I9I2, Basson wrote of the inspiration for further classical study which he had received from hearing him lecture - 'an inspiration,' (he continues) 'which a South African Student, coming from a country, where the materialism of the gold mines and the happy and innocent indifference of a pastoral population lend the tone to the culture of the day, very much stands in need of ${ }^{\text {II }}$ Eight years later, he expresses surprise to have received a contribution of $f_{5} 0^{\circ}$ to his appeal fund from Friedrich Heinrich (Fritz) Hirschhorn, a director of the De Beers diamond company: 'It's a good sign,' he tells Wilamowitz, 'for in general the De Beers men are big pro-British imperialists, like the predecessor of them all, Cecil Rhodes'. ${ }^{\text {I2 }}$ The value of intellectual culture after the War, it turns out, survived in unlikely places, even among those who had not themselves benefited from higher education.

This minor episode in cultural history, centred on a country far from the battlefields of Europe, thus juxtaposes dramatic change with the desire for restoration; that is, for continuity. A struggle over continuity and change might indeed be said in certain regards to characterize the decade which followed the War. The changes are, as ever, more immediately striking than the continuities; leaving aside the more extreme manifestations of political change which occurred in continental Europe, in Britain we may recall (for example) the series of Acts of Parliament of I9I8 and I9I9 which, with some limitations, permitted women to vote and to stand for parliamentary election, and removed disqualification from professions and public offices on grounds of sex or marriage. ${ }^{33}$ The War marked, and was seen to mark, a watershed, indeed a

Io Basson, letters to Wilamowitz, 7 October and 4 November 1920. The main donors were Fritz Hirschhorn (I867-I949), on whom see further below and Arkin (I98I); and H. Malcomess, almost certainly Hermann W. Malcomess (I848-I92I), founder of a successful agricultural-business company in the eastern Cape, on whom see Puschmann (1970).

I I Basson, letter to Wilamowitz, 25 April I9I2. This is the only letter in the collection in which Basson writes in English.

I2 'Es ist ein gutes Zeichen, denn im allgemeinen sind die "De Beers" Herren grosse probritische Imperialisten, wie ihr aller Vorgänger, Cecil Rhodes': Basson, letter to Wilamowitz, 4 November 1920 (translation mine).

I3 The Representation of the People Act I9I8 (Royal Assent 6 February); the Parliament (Qualification of Women) Act I9I8 (2 I November); the Sex Disqualification (Removal) Act I9I9 (23 December). 
chasm in time. ${ }^{\mathrm{I}}{ }^{4}$ In his recent study of the literature of the War, Randall Stevenson writes of 'a sense of interruption in the broader movements of history' during and after the conflict, of '[f]eelings of radical disjuncture [.. . ] described in many accounts of the times', citing, among other testimonies, J. B. Priestley's image of the War as 'a great jagged crack in the looking-glass', and H.D.'s remark in her autobiographical novel Bid Me to Live that '[t] he past had been blasted to hell [. . .]; already, in I9I 7, the past was gone. It had been blasted and blighted, the old order was dead' ${ }^{\text {I5 }}$

The abolition of compulsory Greek at Oxbridge aligns neatly with this sense of division, and indeed Judith Raphaely's analysis of the fifty-year history of the issue concludes that '[i]t was the War, and the social upheaval it implied, which forced the debates sharply into perspective, and to resolution [...] Like so much else, Compulsory Greek was a casualty of far greater "clashes of arms"" I6 But institutionally, as Stray has argued, Classics in Britain metamorphosed after I9I9 into a somewhat different creature with predominantly Latin DNA. ${ }^{17}$ And in the wider world beyond the educational institutions one might have seen things which seemed to imply that the War had brought no change at all to Britain's relationship with the classical past, particularly as constructed in the closing decades of the previous century. For example, Sigismund Goetze's set of murals in the Foreign Office depicting Britannia, installed in I92 I, was rounded off with Britannia Pacificatrix, where a very Roman figure dominates a post-War international scene, underlining the allusion to the pax Augusta implicit in the title; ${ }^{\mathrm{I}}$ and with the Empire coming to extend further than ever before with the territorial mandates granted by the League of Nations, it is no surprise to find the 'Pageant of Empire' staged at the British Empire Exhibition of 1924 evoking in certain respects the inauguration of the

I4 Cf. Hynes (I990: ix): 'Men and women after the war looked back at their own pasts as one might look across a great chasm to a remote, peaceable place on the other side.' Hynes is concerned here with perceptions of the War, and his book with what he calls the 'Myth of the War'; but it is important to note that by this he means 'not a falsification of reality, but an imaginative version of it' (ibid.), and to bear in mind too that in certain important respects the world after the War was objectively very different from the world before the War (to give a single unemotive example, cited by Stevenson 2013: 202, the national debt in Britain increased from $£ 645$ million in I9 44 to $£ 7,800$ million in I9I9). For the War as a 'chasm', cf. also Woolf (20 I I: 264).

I5 Stevenson (2013: 74); Priestley (I966: 88); H.D. (I984: 24). Note, however, that in the same passage H.D. can deny this sense of complete separation from the pre-War world, writing of 'an infinitely narrow thread', a 'silver-cord that bound them to that past [...] Reality lived in the minds of those who had lived before that August [I9I4]'. H.D.'s own engagement with Classics is explored in depth by Gregory (I997), with discussion of the relationship of this to the Great War at, e.g., pp. 22-28.

I6 Raphaely (I999: 93).

I7 Stray (I998: 27I-97, with helpful observations at 269-70).

I 8 On Goetze's murals, see Willsdon (2000: I09-2I, with Colour Plate XVI); Mirkovic (20I4). 
Flavian Amphitheatre (Colosseum) by Titus in $\mathrm{AD} 80 .{ }^{19}$ But just as the Empire was in fact at its tipping-point, so the jingoistic use of classical models represented by spectacles such as these tends to obscure the fact that the place of Classics in the cultural weave of British society was currently under re-evaluation.

One of the chief arenas within which this re-evaluation was taking place was modernist literature. In the I920s, modernist writers grappled in different ways with a package of problems to which the War was central: ${ }^{20}$ for example, the near-inexpressibility of things that had happened or had been seen (Walter Benjamin's observation about the silence of men returning from the battlefield, 'poorer in communicable experience', is often cited in this connection $^{2 \mathrm{I}}$ ); the sense of discontinuity to which I have already referred; and the relation of that to both literary and broader cultural traditions in which Classics was thoroughly implicated. In the pre-War world, to quote Paul Fussell, '[e]veryone knew what Glory was, and what Honor meant'; ${ }^{22}$ but although the heroic model that went alongside that 'knowledge' could no longer offer itself so glibly after the conflict (or indeed during the conflict, as we see, for example, in the fine poem of Patrick Shaw-Stewart which supplies the title of Elizabeth Vandiver's Stand in the Trench, Achilles $^{23}$ ), Classics retained an important place in the thought and work of many of the leading modernists. ${ }^{24}$ The response of T. S. Eliot and Ezra Pound to the post-

I9 A contemporary pamphlet by the builder, Sir Robert McAlpine, celebrating the completion in 1923 of the Empire Stadium at Wembley, built with the Exhibition in view, explicitly compares it (favourably) to the Colosseum (quotation in Wilson 2006: 274-5, Brendon 2008: 33I). In an exhibition designed to display to its audiences the British Empire in microcosm, the 'Pageant of Empire' — subtitled 'An Historical Epic' presented not merely a cast of I 5,000 people but a very large number of domestic and exotic animals, a feature of Roman arena spectacles, including those associated with the inauguration of the Colosseum (see especially Martial's Liber spectaculorum). On the pageant, see Benedict (I99I: 7); on the Exhibition more generally — with a feel for the Roman parallel — Brendon (2008: 33I-3).

20 On modernism and the Great War, see now MacKay (20I7: I-6o), with much of relevance to the present discussion.

2 I Benjamin (i973: 84).

22 Fussell (2013: 22).

23 Vandiver (2010); discussion of Shaw-Stewart and his poem ('I Saw a Man This Morning') at pp. 263-77.

24 It should be kept in mind, however, that not all the many variations of 'modernism' (a notoriously capacious and slippery term) demonstrated such engagement: the Futurists in Italy, for example, had already before the War expressed violent rejection of the cultural past. And yet even in its rejection of the classical, Futurism paradoxically conceded its cultural centrality and power, as F. T. Marinetti's famous comparison in the Futurist Manifesto of 1909 implies: 'a roaring car that seems to ride on grapeshot [or 'machine-gun fire' (mitraglia)] is more beautiful than the Victory of Samothrace' (Kolocotroni et al. I998: 25I). On the complexities and problematics of the term 'modernism' and the historical development of the concept, see Latham and Rogers (20 I5). 
War crisis - though it should be emphasized that the crisis in literature and culture which they and others perceived was also informed by other currents, within and without the $\operatorname{arts}^{25}$ — was to make use of tradition in the service of innovation. For Eliot, famously, '[the] significance, [the] appreciation [of the poet or artist] is the appreciation of his relation to the dead poets and artists' ${ }^{26}$ Pound's slogan, 'Make It New', implies the renewal of a pre-existing thing. ${ }^{27}$ This position can itself be seen as a classical reflex; at the same time, both Pound and Eliot drew massively on classical texts in their poetry, in ways that impose exceptional demands on the reader, confronted with an Alexandrian level of learning and allusivity and, in the case of The Waste Land, a mystique arguably increased rather than lessened by Eliot's explicatory notes. But however allusive and difficult these poems may be, they can be read both as a figure for the fragmentation of post-War culture and the destructiveness of the War itself ${ }^{28}$ and as an assertion of literary, including classical, tradition, at once a recognition of the reality of the War and a denial of its existence as a chasm in history. With similar ambivalence, James Joyce's Ulysses, completed in I92I, renews Homer in a nostos narrative that resonates with the Great War in various ways (not least simply through the use of a post-war poem as its model) and yet elides it through its setting in 1904, marking it as an event that was to come but has now passed, a sutured wound. ${ }^{29}$

Against this background, I want in this article to consider (inevitably briefly and partially) how Classics is exploited and represented in works by two major modernist writers which look back at and attempt to articulate a response to the Great War. My interest here lies both in the associations which Classics may be held to possess in these texts and in the hermeneutic value of specific references or allusions. But I want to underline from the start that, while I have to this point tended, perhaps unavoidably, to present 'Classics' as a unitary thing, it actually takes many forms and lies open to various constructions and appropriations. It is, then, however enduring (like Odysseus), inherently unstable, and in what follows I hope, among other things, to illustrate some of the ways in which this instability manifested itself in the unstable decade of the r 920 .

25 For an excellent summary analysis see Lewis (2007: 2-3).

26 Eliot (I95 I: I 5).

27 On the origins, history, and shifting meaning of 'Make It New', see North (2013: I62-7I).

28 Cf. Hynes (I990: 343): 'The Waste Land is more than an accumulation of image-fragments; it is a poem that takes fragmentation as its formal principle, as though the visual reality of the Western Front had imposed itself on language.'

29 On Ulysses and the Great War, see Spoo (I986); Fairhall (I993: I6I-2I3, esp. I6I-70). 
II

Virginia Woolf's career as a novelist begins and ends in the middle of a world war. Her first novel, The Voyage Out, appeared in March i9 I5; her last, Between the Acts, was published posthumously, a few months after her death, in the summer of I94I. Throughout her fiction, the subject of war itself is treated obliquely, distanced $3^{3 \circ}$ yet at the same time echoes of the great conflict of I9I4-I 8 are hauntingly present, ${ }^{3 \mathrm{I}}$ particularly, perhaps, in her first three novels from the following decade: Mrs. Dalloway (1925), To the Lighthouse (1927), and the earliest, Facob's Room, which appeared in the same year, I922, as Ulysses and The Waste Land. All three comment on the War in different ways, and all draw on Classics in doing so.

Woolf's fascination with Greek and with Greece is well known. In a much-quoted letter of I900, at the age of eighteen, she writes that 'Greek [...] is my daily bread, and a keen delight to me'; ${ }^{2}$ and the Greek world became part of the baggage that she carried with her through her life. ${ }^{33}$ But her engagement with it is complex. Facob's Room, which will be my focus here, gives an account of the life from early boyhood of Jacob Flanders, whose very name offers a clear pointer to his death in the War, though this is not described and indeed is presented as having occurred only on the final page of the novel and inexplicitly, its suddenness in the narrative reflecting the contingency of the event and the immediacy of the extinction of a life in its prime. Throughout the work, the reader is denied any consistent purchase on Jacob, who is a kind of absent presence, flitting here and there amongst a huge cast of characters, a sense enhanced by the fragmentary nature of the narrative and the elliptical, impressionistic style Woolf employs. A passage in To the Lighthouse evokes the moment in the Odyssean Nekuia when Odysseus attempts to embrace the shade of his mother:

Mr. Ramsay stumbling along a passage one dark morning stretched his arms out, but Mrs. Ramsay having died rather suddenly the night before his arms, though stretched out, remained empty.

To the Lighthouse, II.3, p. I Io ${ }^{34}$

30 Cf. Gordon (2006: 202), thinking in particular of To the Lighthouse: "[T]o come to terms with the first world war [...] [Woolf] devised a counter-history in which war is not the centre-piece but a vacant period through which time rushes.' On Woolf and war, see esp. Hussey (I99I); on the Great War specifically, Levenback (I999).

3I Cf. Lee (I997: 34I): 'The First World War as a catastrophic break [...] overshadows Virginia Woolf's work.'

32 Letter to Emma Vaughan, June I9oo (Woolf I975-80: I.35).

33 Valuable studies include Fowler (1999); Spiropoulou (2002); Lamos (2006); Koulouris (20I I); Romero Mariscal (20I2).

34 I follow the Shakespeare Head Press edition (Woolf I992). Cf. Hom. Od. I I.204-8; also Virg. Aen. 2.792-4 (Aeneas and Creusa's ghost). 
There is something equally wraithlike about Jacob, whose end is foreshadowed not only by his name but by the numerous images of death deposited throughout the work, and whose disappearance from life is emphasized in the concluding two lines, where his mother asks his friend Bonamy what she is to do with a pair of Jacob's old shoes. $^{35}$

Classics, particularly Greek, plays an important role in Jacob's formation in a work often seen as a fictional or (like Orlando, I928) parodic biography, ${ }^{36}$ almost an anti-biography. As a child in Scarborough, he is taught Latin by a clergyman, Mr Floyd, who, on the point of moving from the town, invites Jacob and his brothers 'to choose whatever they liked in his study to remember him by'; Jacob's choice of an edition of Byron might well be seen as marking a romantic attachment to Greece (ch. 2, p. I 5). Going up to Cambridge in r9o6, Jacob is acculturated into a homosocial world in which Greek and Latin hold a central position, and where nothing changes: a don, Sopwith, 'has praised the sky any night these twenty years'; another, Erasmus Cowan, who 'intone[s] Latin, Virgil, and Catullus, as if language were wine upon his lips', 'still chuckles at the same stories' (ch. 3, pp. 3I-32). To this world, women are marginal; an elderly female classicist, Miss Umphelby, 'sings [Virgil] melodiously enough, accurately too' (ch. 3, p. 32), but is beset by the thought of what she should wear if she met him, and

lets her fancy play upon other details of men's meeting with women which have never got into print. Her lectures, therefore, are not half so well attended as those of Cowan, and the thing she might have said in elucidation of the text for ever left out.

Jacob's Room, ch. 3, p. 33

At a service in King's College Chapel, Jacob wonders, in annoyance, why women should be allowed to take part in it:

No one would think of bringing a dog into church [...] a dog destroys the service completely. So do these women - though separately devout, distinguished, and vouched for by the theology, mathematics, Latin, and Greek of their husbands.

Jacob's Room, ch. 3, p. 25

Later in his life, when he visits Greece, Jacob has a similar reaction to women on the Acropolis, at the Erechtheum (ch. I2, pp. I25-6). ${ }^{37}$ Woolf's description of the

35 Jacob's Room, ch. I4, p. I48. References follow the Shakespeare Head Press edition (Woolf 2004).

36 See, e.g., Lee (1977: 84); Whitworth (2005: го6).

37 Note also, however, that while Jacob at first expresses irritation with the Caryatid statues ('These statues annulled things so!'), one of them comes to remind him of Sandra Wentworth Williams, with whom he is in love (ch. I2, pp. I26, I24). Similarly ambiguous is Jacob's attitude to another lover, Florinda, at ch. 6, p. 67: her 'stupidity' causes 'a violent reversion towards male society, cloistered rooms, and the works of the classics'; 
service at King's shows how this misogyny is imbricated with male values of authority and order, which in turn, she implies, point to war and death: ${ }^{8}$

Look, as they pass into service, how airily the gowns blow out, as though nothing dense and corporeal were within. What sculptured faces, what certainty, authority controlled by piety, although great boots march under the gowns. In what orderly procession they advance.

Jacob's Room, ch. 3, p. 24

Jacob is thus shaped by an exclusive system that is unwittingly undermined by its own self-assurance. The exclusivity discloses itself in a variety of ways: in his scornful response, for example, to an act of bowdlerization by a professor at a provincial university, in which, with Cambridge condescension, he cites Shakespeare and Aristophanes and repudiates 'modern life' (ch. 5, p. 56). It is precisely the entrenched position of social superiority informed by cultural claims on the past, including the classical past, from which Jacob repudiates 'modern life' that (Woolf suggests) delivers his generation to war. A snapshot of his room in Cambridge brings before us an essay entitled 'Does History consist of the Biographies of Great Men?' and a range of books, including lives of the Duke of Wellington, whose martial heroism is later (ch. I3, p. I39) recalled through mention of the statue of Achilles which dominates his monument in London, and 'a Greek dictionary with the petals of poppies pressed to silk between the pages' (ch. 3, p. 30) - 'an image', writes Rowena Fowler, 'that suggests that Liddell and Scott lead straight to the trenches'. ${ }^{39}$ Part of the tragedy lies in the conviction of Jacob and his friends that the Greece they have imbibed and assimilated in their paideia is true, and that they understand it:

The Greeks - yes, that was what they talked about - how when all's said and done, when one's rinsed one's mouth with every literature in the world [. . . ] it's the flavour of Greek that remains. Durrant quoted Aeschylus-Jacob Sophocles. It is true that no Greek could have understood or professor refrained from pointing out-Never mind; what is Greek for if not to be shouted on Haverstock Hill in the dawn? [...]

"Probably," said Jacob, "we are the only people in the world who know what the Greeks meant."

Facob's Room, ch. 6, pp. 6I-62

but as she looks at him, apologetic and beautiful, 'then he knew that cloisters and classics are no use whatever'.

38 Cf. Whitworth (2005: $157-67)$ on the connections between male education and war and militarism in Woolf's later novel The Waves (I93I).

39 Fowler (I983: 347). On the relationship between Jacob's education, the 'Greek illusion' (cf. below), and the War, see further Froula (2005: 63-84, esp. 63-67). 
Almost immediately after this the (female) narrator informs us that 'Jacob knew no more Greek than served him to stumble through a play. Of ancient history he knew nothing' (ch. 6, p. 62); and later she implicates women too in this male fantasy:

[I]t is the governesses who start the Greek myth. Look at that for a head (they say) - nose, you see, straight as a dart, curls, eyebrows — everything appropriate to manly beauty [...] And the Greeks could paint fruit so that birds pecked at it. First you read Xenophon; then Euripides. One day - that was an occasion, by God - what people have said appears to have sense in it; "the Greek spirit"; the Greek this, that, and the other; though it is absurd, by the way, to say that any Greek comes near Shakespeare. The point is, however, that we have been brought up in an illusion.

Facob's Room, ch. I2, p. II 4

Though this upbringing may seem to Jacob, in a moment of bored reflection, 'very distasteful' (ch. I2, p. I I4), he has received little enlightenment, even from Plato. In his room in London, he reads the Phaedrus, which, we are told:

$[\ldots]$ is very difficult. And so, when at length one reads straight ahead, falling into step, marching on, becoming (so it seems) momentarily part of this rolling, imperturbable energy, which has driven darkness before it since Plato walked the Acropolis, it is impossible to see to the fire. ${ }^{4^{\circ}}$

Jacob's Room, ch. 9, p. 90

Troping Jacob's reading of the text in terms of ordered military movement ('falling into step, marching on'), with the illusion it produces ('so it seems') of standing shoulder to shoulder with Plato, the narrator suggests that Jacob has been seduced by the rhythms of Plato's text into a wholly unSocratic understanding of the dialogue, where rhetoric has defeated truth. And when the dialogue is done, and Plato's argument 'stowed away in Jacob's mind', far from driving darkness before it, Jacob's mind 'continues alone, onwards, into the darkness' (my emphasis). The image of the dark recurs, strikingly, at the end of the penultimate chapter, where the ships in the Piraeus fire their guns and '[d]arkness drops like a knife over Greece' (ch. I3, p. I46). ${ }^{4 \mathrm{I}}$

Seen by two female companions as quite literally statuesque, an image that immediately evokes the 'sculptured faces' processing through King's College Chapel, Jacob is fixed in stone, endowed with the heroic, Achillean attributes of a past world — fit, indeed, for a museum: ${ }^{42}$ 'Jacob. You're like one of those statues. ... I think

40 The suggestion seems to be that Jacob is too engaged with the dialogue to deal with seemingly mundane tasks.

4I The firing of the guns is a ritual marking the end of the day (see ch. I2, p. I23); in the immediate context, however, as well as that of the novel as a whole, it is natural to take the reference also as a marker of the arrival of the War.

42 Compare the characterization of Christopher Tietjens in Ford Madox Ford's Parade's End (discussed below) as a 'museum piece' (Brasme 20 15: I42, with reference to Ford 2010: 169). 
there are lovely things in the British Museum, don't you?', says Florinda (ch. 6, p. 65), while Fanny Elmer's vision of him during his absence, visiting Greece, is reinforced by a specific example of one of those 'lovely things', the statue of the 'battered Ulysses' (ch. I3, p. I4I). To Fanny, Jacob is, like a statue, 'noble, and eyeless' (ch. I3, p. I4I), the latter adjective suggesting both the illusory world in which Jacob now lives and the unseeing corpse he will soon become. But more than that, he is like Ulysses, and must surely return to her; but not only does Jacob not return to her after arriving back in London, when he leaves again for the War he does not return at all, in a novel that rejects the narrative of nostos. ${ }^{43}$ The words in which Fanny's thoughts of hope and desperation are presented the last time we see her ('he would, he must, come back to her', ch. I3, p. I42) are echoed at the start of the onepage concluding chapter, where Bonamy, looking around Jacob's room, muses: 'He left everything just as it was [...] Nothing arranged. All his letters strewn about for any one to read. What did he expect? Did he think he would come back?' (ch. I4, p. I47).

In Jacob's Room, then, Classics, and in particular Greek, exists as a romantic myth, holding a central place within a static worldview embodying outmoded concepts and values soon to be exploded by the War. But this negative characterization should not lead us to conclude that the value of Classics itself has been destroyed. Theodore Koulouris, in a book that seeks to draw a distinction between 'Hellenism', understood as a cultural package of the kind I have described, and what he terms Woolf's 'Greekness', ${ }^{44}$ alerts us to a hint of a new perception emerging in Jacob as, sitting on the Acropolis, he has a sudden realization that 'Greece was over; the Parthenon in ruins; yet there he was' (ch. I2, p. I25). 'The ruins of the Parthenon,' writes Koulouris, 'no longer redolent of its classical splendour, emit a strange kind of attraction which transcends the illusoriness of [Jacob's] Cambridge Hellenism, an attraction which powerfully links experience with the ragged contours of reality'. ${ }^{45} \mathrm{~A}$ little earlier, at Olympia, Jacob has written to Bonamy that he intends to come to Greece every year of his life, saying, 'It is the only chance I can see of protecting oneself from civilization' (ch. I2, p. I2I), a statement which puzzles Bonamy, but which we might take as neatly ambiguous: is this 'civilization' the 'modern life' that we have seen Jacob repudiate, or is it the culture of the Hellenic myth which has so

43 See Flack (20 I4: I4I-8).

44 See Koulouris (201 1: 6-8). Note in particular his description of Hellenism, or 'British Hellenism', as 'a specialised domain, which treated classical Greece as part of a certain academic discipline' (his emphasis) and 'a cultural rubric evocative of nineteenth-century, western European tendencies to identify the study of Greek with academia, scholarly pursuits and excellence, though also and above all, particularly from a British perspective, with masculinity [and] male homosociality [...]'; the concept also includes 'the tendency to consider the study of classics at the time as the ideal breeding ground of social exclusivity' $(6-7)$.

45 Koulouris (201 I: 219). 
formed him ${ }^{46}$ In any event, recognition of the falsity, the misreading, of the 'Greece' that forms part of the illusion in which Jacob has been caught up implies the possibility of reading it in other, truer, ways - the constructive use to which Woolf puts Classics in the post-War cultural critique represented by this novel itself demonstrating the plasticity of the material, of whose protean quality the development of reception studies has made us more aware.

To much the same period as Facob's Room belongs Woolf's essay 'On Not Knowing Greek', published in her collection The Common Reader (1925). Difficult and elusive, the essay is concerned to stress the remoteness of Greek literature, the Greek language, the Greeks themselves, who 'remain', says Woolf, 'in a fastness of their own' (p. 39). ${ }^{47}$ Misunderstanding is a constant risk:

When we read these few words cut on a tombstone, a stanza in a chorus, the end or the opening of a dialogue of Plato's, a fragment of Sappho [...] - are we not reading wrongly? losing our sharp sight in the haze of associations? reading into Greek poetry not what they have but what we lack? [...] Back and back we are drawn to steep ourselves in what, perhaps, is only an image of the reality, not the reality itself, a summer's day imagined in the heart of a northern winter.

'On Not Knowing Greek', pp. 54-55

This uncertainty stands fully opposed to Jacob's exuberant claim that he and Timothy Durrant are 'probably [...] the only people in the world who know what the Greeks meant', revealing an awareness of the gap between 'us' and the Greeks that is lost on Jacob. This gap may make 'reading wrongly' inevitable, after all; yet such a thing may be positive and liberating, as in the case of Sara Pargiter in The Years (I937), whose reading of Sophocles' Antigone, full of distorted impressions, makes the play relevant and meaningful to her own situation, 'entombed' as she is in the life of a woman with a physical deformity, and in so doing underlines the creative power of interpretation. ${ }^{4^{8}}$ But while recognizing and demonstrating the shifting quality of Classics, Woolf paradoxically also asserts its stability. Having earlier acknowledged the 'vast catastrophe of the European war', she concludes the essay by saying that 'it is to the Greeks that we turn when we are sick of the vagueness, of the confusion, of the Christianity and its consolations, of our own age' (pp. 54, 59). It is among them that 'the stable, the permanent, the original human being is to be found' (p. 44).

\section{III}

Woolf's novels of the War can scarcely be called, in the usual sense of the phrase, 'war novels'. In the final part of this article I want, by way of comparison and contrast, to consider one such example from a decade which produced numerous works belonging to this subgenre — or rather, a set of four such examples, Ford

46 Koulouris (20I I: 220) seems to take it as the latter.

47 References follow Woolf (I925). For excellent observations, see Evangelista (2009: I-2). 48 Cf. McCoskey and Corbett (2012: 468-70). 
Madox Ford's tetralogy Parade's End, published between I924 and I928. ${ }^{49}$ Like much other modernist work, including that of Woolf, Parade's End evinces a profound concern with time and change, slippages and fractures, endings and beginnings. Ford, himself a survivor of the Somme, here looks back at the Great War and the surrounding years with a focus on the experiences of Christopher Tietjens, a member of a wealthy landowning family from Yorkshire, an English Tory with traditional values. Sharply intelligent, Tietjens belongs to a class which 'administered the world' ( $S D N$, I.I, p. 4), holding a post in the Imperial Department of Statistics, imposing order and control on Britain and its Empire - illusory, of course, as the War, which takes him as an officer to the front line, rapidly proves. Inveigled before the War into an unhappy marriage with a serially unfaithful socialite wife, Tietjens comes through the conflict to establish, in greatly reduced circumstances, a long-deferred alternative relationship with Valentine Wannop, suffragette daughter of a novelist mother and an academic father with a keen interest in women's education. In one respect — to quote Max Saunders - Parade's End may be seen as 'an elegy [...] for an England that was no more', ${ }^{\circ}$ an expression of loss and nostalgia; but, as Saunders also demonstrates, such a view omits much and tends to suggest in Ford a conservatism that cannot properly be attributed to him. Saunders writes: ' $[\mathrm{H}]$ is politics were too paradoxical and flexible to be partisan. $\mathrm{He}$ understood politics, as he constructed novels, by moving amongst opposing viewpoints' ${ }^{5 \mathrm{I}}$ In examining the reception of Classics in Parade's End, I want to suggest a way in which the work might be seen as a constructive and forward-looking engagement with issues of societal transformation, and at the same time to map that reception on to the analysis undertaken in the earlier parts of this paper.

Classical reference and allusion in the tetralogy as a whole is sporadic, but there are recurrent threads. One of these concerns the Alcestis of Euripides, a play close to Ford's heart, which he had translated (or adapted) immediately after the War. ${ }^{52}$ A play about a journey to hell and back lends itself easily to exploitation in a work in which the central character departs for and finally returns from the unrelenting horror of the battlefields of France, but Ford rings interesting variations on the story: Christopher Tietjens is at different points aligned with Admetus, Apollo, and Heracles, who rescues Alcestis from the underworld as Tietjens rescues a young soldier buried by earth following an explosion — the soldier, aptly (or ironically)

49 The four novels are: Some Do Not ... (= SDN); No More Parades (NMP); A Man Could Stand Up- (AMCSU); Last Post $(L P)$. On the characterization of the four as a tetralogy, which is not entirely unproblematic, see Ford (20IIc: li-lv). References are to the Carcanet Press edition (Ford 20го, 20 г га, 20 I Ib, 20 I Ic).

50 Saunders (i996: II.204).

5I Saunders (I996: II.205). On Ford's politics, with particular reference to Parade's End, see Saunders (I996: II.204-I I); more broadly, Gąsiorek (2015).

52 See Saunders (I 996: II.78-9 with n. 24); Ford (20 I Ib: xliv-xlvi) (with curious omissions and errors). 
named Duckett, in looks reminds Tietjens of Valentine Wannop, herself compared with Alcestis on several occasions. In one of these instances, the scene of Alcestis' address to her marriage-bed is evoked, though with implicit inversion: the situation is not one of imminent departure and separation, but of return and union, achieved on Armistice Day. ${ }^{53}$ The notion of return from war will naturally also call to mind that other underworld visitor, Odysseus, and in this regard Parade's End can be seen to resemble Ulysses and Facob's Room in offering another variation on the nostos theme. ${ }^{54}$ The Penelope to whom Tietjens returns is not his wife but a young woman with whom he is to live quasi-maritally, with negative social consequences, while his actual wife, Sylvia, is not only no Penelope but a vindictive woman who, in the final volume, set some years later, ${ }^{55}$ brings about the destruction of the great and ancient cedar tree on the Tietjens family estate in Yorkshire that symbolizes the continuity of the family and the past itself. More than this, the tree's association with marriage - '[f]or thirty miles round Groby [people] made their marriage vows by Groby Great Tree' (LP, I.4, p. 8o) — links it to Odysseus' marital bed, built from a living olive tree and immovable ${ }^{56}$ its destruction, then, though painful for Christopher, can also be read as a powerful symbol of the death of his relationship with Sylvia and as (paradoxically) freeing him into a new future, more fluid, less certain, in a changed and changing world. The bed which recalls to Valentine the story of Alcestis - a camp bed — is, in contrast, easily movable, indeed moved ( $A M C S U$, III. I, pp. I89-90; III.2, p. 213); and in this context we might note that, as hinted at throughout the tetralogy, by the time of the last volume Tietjens has become a dealer in antique furniture, thus maintaining a connection with the past without being bound to it. ${ }^{57}$

It is, however, a Latin rather than a Greek thread that is of most relevance to my argument in this paper. Amid the battles in northern France - it seems to be late in I9 $16^{5^{8}}$ — two British officers engage in a literary contest. ${ }^{59}$ One - Captain Tietjens — challenges another, Captain McKechnie, ${ }^{60}$ to provide him with the fourteen endrhymes for a sonnet, and undertakes to write the sonnet from scratch in less than two and a half minutes. McKechnie, who has already been identified as a 'Vice-

$53 A M C S U$, III. I, pp. I90-I; Eur. Alc. I75-88. Note especially how Valentine, like Alcestis, kisses the bed.

54 Cf. Flack (2014). On the underworld theme in Parade's End and elsewhere in post-First World War literature (Pound's Canto I, for example), see Ford (2o I Ic: xl-xliii).

55 For the chronological problems posed by Last Post, see Ford (20 I Ic: xxvii-xxxi).

56 Hom. Od. 23.177-204.

57 On the furniture theme, see Ford (20 I Ic: lii-lv).

${ }_{5} 8$ Throughout Parade's End there are few specific indications of chronology. Scattered references in $N M P$, however, point to a date of November/December I9 6 for the events of this novel.

59 For fascinating, closely relevant, background in Ford's own experience during the War, see Hueffer (i9i8: i io, i I3-25).

6o Repeatedly referred to in the text as 'Mackenzie', until Tietjens discovers his real name. 
Chancellor's Latin Prize man', ${ }^{61}$ who can speak five languages and read two more, '[a]nd Latin and Greek, of course' (NMP, I.I, p. 28), responds by saying that, if Tietjens does it, he will translate his poem into Latin hexameters in less than three minutes. 'They were like men', says the narrator, 'uttering deadly insults the one to the other' (NMP, I.2, pp. 37-38). When Tietjens completes his task - in two minutes, eleven seconds - McKechnie takes the sonnet, but says that he will not look at it there and then; rather, he will 'turn it into Latin in the mess: in the time stipulated' (NMP, I.2, pp. 44-45).

This scene occurs early in the second novel, No More Parades. In the middle of the third, A Man Could Stand Up-, when the action has moved to April i9i8, McKechnie presents to Tietjens a crumpled envelope, requesting that he observe that the seal is unbroken. In the envelope is the sonnet, still untranslated. Tietjens here recalls how he had provoked the competition and written the sonnet to distract himself 'in a moment of stress' ( $A M C S U$, II.3, p. I20). At the same time, the contest can be construed as a way of reconfiguring the War into something familiar to men of the education of Tietjens and McKechnie, and thus controllable. For McKechnie, indeed, the competition is what enables him to maintain some vestige of sanity in circumstances where he is on the edge of mental disintegration; in showing Tietjens the envelope, '[h]e was only pointing out that he could pit his Intellect and his Latinity against those of Tietjens: that he could do it when the great day came!' ( $A M C S U, \mathrm{II} .3$, p. I20). One might say, then, that not translating the sonnet is essential to McKechnie's mental survival; and yet his incapacity to complete the task seems iconic of the stasis and futility of the War itself, underlining the meaninglessness of both. Further, McKechnie's competence in Latin - Vice-Chancellor's Prize man or not - is called into question by Tietjens:

The fellow wasn't even a decent Latinist. Or verse-maker, though he was always boasting about it to the impossible, adenoidy, Cockney subalterns who made up the battalion's mess. He would translate their chits into Latin verse. ... But it was always into tags. Generally from the Aeneid. Like:

“Conticuere omnes, or Vino somnoque sepultum!"

That was, presumably, what Oxford of just before the War was doing. A Man Could Stand Up-, II.3, p. I2 I

Though Tietjens' evident dislike of McKechnie ${ }^{62}$ may colour the judgement pronounced here, the passage marks McKechnie's knowledge of Latin, institutionally honed in pre-War Oxford, as enabling him to do no more than perform a kind of

6I $N M P$, I. I, p. I5, with several references thereafter.

62 For this dislike, which appears to relate at least partly to class distinction and Oxbridge rivalry, see, e.g., $A M C S U$, II.3, pp. I I9-20 (with focalization through Tietjens): McKechnie 'still more of a bore' (I I9); possessing 'an Oxford-Cockney accent' (I 20); 'Several moments of stress they [Tietjens and McKechnie] had been in together. It ought 
trick, which Tietjens similarly recognizes his sonnet to be. ${ }^{63}$ That is to say, Latin is reduced to a social currency, its possession an indicator of status - the reference to the Cockney subalterns underlines the point - in a world now in the process of being swept away. And yet McKechnie's tags can be read as commenting suggestively on the War, the times, and indeed Ford's own project. Conticuere omnes, 'all fell silent', the famous opening words of Aeneid 2, ${ }^{64}$ bring to mind Aeneas' account of the fall of Troy, which he is about to deliver, and which itself begins with the notion of silence, Aeneas' unspeakable grief (infandum [...] dolorem, Aen. 2.3). As Tietjens reflects on the contest with McKechnie and on McKechnie's faux-Latinity, the two of them are in a trench, under recurrent artillery fire; silence here manifests merely as the cessation of destructive noise. ${ }^{65}$ But there is a broader silence, the silence of the unspeakability or incommunicability of the War, which I mentioned earlier. McKechnie's tag might well be seen as a reflection of this idea, and Ford's novel itself as an attempt to articulate, like Aeneas, what is infandum. The other Latin phrase, taken from the same book of the Aeneid (2.265), refers to the Trojans, 'buried in wine and sleep', as the Greeks in the wooden horse emerge to admit their comrades to the city. In this sequence of novels, with its underworld echoes, the burial in the trenches of men such as Duckett, and the presence of death in various guises throughout, sepultum will naturally carry more than metaphorical weight; and after Christopher Clark's revisionist account of the origins of the Great War, it is hard not to feel beneath somno a tremor of the idea of the European belligerents sleepwalking into I9 $4 .{ }^{66}$ But it is also of interest that Virgil is in fact here misquoted: the words in the poem are not vino somnoque sepultum but somno vinoque sepultam (of the city, urbem $).{ }^{6}$ How should we read this? We might speculate that McKechnie is a better Latinist than Tietjens claims, and deliberately inverts the order of the nouns and changes the gender of the participle the better to suit the phrase to rum-drenched

to have formed a bond between them. It hadn't. ... Imagine having a bond with a Highland-Oxford-Cockney' ( I20).

63 Implicit at $A M C S U$, II.4, p. I23; made explicit in Tom Stoppard's BBC dramatization (Stoppard 2012: 310).

64 Echoed in the conclusion to Book 3 ( 7 I 6-I 8$)$, at the end of Aeneas' account of the fall of Troy and the ensuing travels of the Trojans.

${ }_{5}$ Cf. the reference a few pages before to 'all the German artillery on that front, [which,] imagining that God knew what was the matter, had awakened and plastered heaven and earth and everything between for a quarter of an hour with every imaginable kind of

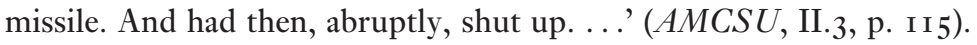

66 Clark (20I3); note especially the concluding sentence (p. 562): '[T] I9I 4 were sleepwalkers, watchful but unseeing, haunted by dreams, yet blind to the reality of the horror they were about to bring into the world.'

67 The phrase somno vinoque sepultum occurs at Ilias Latina 730 (in reference to the sleeping Rhesus). For somno vinoque in comparable grammatical/situational contexts, cf. Virg. Aen. 9.I 89, 236, 3I6; Virgil nowhere, however, uses the collocation vino somnoque (which is found only at Livy $25 \cdot 24 \cdot 6,4$ I.3.IO). 
soldiers; or else have recourse to the simpler explanation that Ford just got it wrong. But if we want to see memory-lapse here, we will more constructively attribute it to McKechnie or to Tietjens, who indeed in the first novel, Some Do Not ..., is presented as suffering from amnesia, the consequence of shell-shock. ${ }^{68}$ The crumbling of the pre-War world thus takes in the classically dominated education of the English public school and Oxbridge, which the two men represent (Tietjens, like Jacob Flanders, went to Cambridge ${ }^{69}$ ): Virgil is misremembered even in tags; his text has lost stability. As we will see further below, misquotation and misattribution of Latin seems, in fact, to be a theme in the tetralogy. Most striking is a phrase from Petronius quoted by the Oxford-educated clergyman Duchemin and commented on by Tietjens' ambitious colleague, Vincent Macmaster, which is not in fact to be found in Petronius, or anywhere else in classical Latin; ${ }^{70}$ in the present context it is noteworthy that Duchemin is suffering from dementia.

Latin, then, is associated in Parade's End with stasis, decay, forgetting, and death. But there is another side. In the final part of A Man Could Stand Up-, officers from Tietjens' battalion arrive at his apartment in Gray's Inn to celebrate the Armistice, signed that day. Among them is McKechnie, still carrying his envelope. Ford writes:

Tietjens said: "Oh, yes. The sonnet. You can translate it under Valentine's inspection. She's the best Latinist in England!" He said: "Captain McKechnie: Miss Wannop!" A Man Could Stand Up-, III.2, p. 213

This juxtaposition encapsulates a strong contrast. It has been well prepared for. In the earlier scene in which McKechnie presents the envelope to him, Tietjens not only, as we saw, dismisses McKechnie as a Latinist, but is reminded of Valentine:

68 A theme prominent in Woolf's Mrs. Dalloway, where the veteran Septimus Warren Smith hears sparrows singing 'in Greek words, from trees in the meadow of life beyond a river where the dead walk, how there is no death' (Woolf 2015: 22).

69 At $S D N$, I.7, p. I66, identified as a scholar of Trinity, also Jacob's college (facob's Room, ch. 3 , p. 30).

$70 S D N$, I.5, pp. I I 8-19, I23. The phrase is festinamus, puer callide ('we are in a hurry, crafty boy'); the matter is further complicated by Macmaster's apparent understanding (I23) of callide, 'crafty', as calide, 'passionate'. On the interpretative possibilities, see Saunders' note at Ford (2010: I I 9). It should also be noted that errors of attribution and quotation in Parade's End extend beyond Latin literature into English: see, e.g., $S D N$, II.6, pp. 340-I (with Saunders' notes), where Tietjens muddles passages from Arnold and Rossetti, and confuses the titles of two of Arnold's most famous poems; AMCSU, I.2, p. 36, where Valentine imperfectly recalls the opening of Tennyson's 'Crossing the Bar' (not 'Twilight and evening star' but 'Sunset and evening star'). There is thus a bigger picture, in which the grip of memory on culture is presented as tenuous; and yet the failure of classical memory would seem to have a special potency, given that Classics had for so long represented 'the best' of the past. 
That girl was at least an admirable Latinist. He remarked, with a sort of sardonic glee that, years before, in a dog-cart, emerging from mist, somewhere in Sussex-Udimore! — she had made him look silly. Over Catullus!

A Man Could Stand Up-, II.3, p. I22

The incident Tietjens here recalls takes us back to an episode in Some Do Not ..., where he and Valentine, who have only recently become acquainted, return on a misty midsummer night before the $W^{71}{ }^{71}$ from taking a suffragette friend of Valentine's, on the run from the police, to a safe haven. We have already learned of Valentine's competence in Latin from a conversation with Mrs Duchemin in which Valentine declares that 'I understand Latin almost as well as English because father used to talk it to me and [my brother] as soon as we talked at all'; she might even, she believes, have been 'a classical don at Cambridge' had her father, Professor Wannop, not had different ideas ( $S D N$, I.5, p. I04). In the present episode, Valentine first takes issue with Tietjens' pronunciation of Latin ( $S D N$, I.7, p. I64), and then attacks his misquotation of a passage from Ovid:

"You can't quote a few lines of Ovid without sprinkling howlers in. ... It's vastum, not longum ... "Terra tribus scopulis vastum procurrit" .. . It's alto, not coelo . . ."Uvidus ex alto desilientis. ..." How could Ovid have written ex coelo? The 'c' after the ' $\mathrm{x}$ ' sets your teeth on edge."

Some Do Not ..., I.7, p. I65

The passage under discussion is from Book 4 of the Fasti, the beginning of the account of the rape of Persephone. ${ }^{72}$ Ford liked this part of the poem and quotes from or refers to it in several other works $;{ }^{73}$ in Parade's End the allusion is clearly in keeping with the underworld theme we have already observed. In the jousting which follows, Tietjens asserts his dislike of "cant adjectives like "vast"; to which Valentine responds:

"It's like your modesty to correct Ovid," she exclaimed. "Yet you say Ovid and Catullus were the only two Roman poets to be poets. That's because they mere sentimental and used adjectives like vastum. ... What's 'Sad tears mixed with kisses' but the sheerest sentimentality!"

Some Do Not ..., I.7, p. 166

The phrase quoted here, as becomes completely clear in Tietjens' reply, which gives the Latin, ${ }^{74}$ is, however, neither by Ovid nor by Catullus but by Tibullus (I.I.62 tristibus et lacrimis oscula mixta dabis). This might be taken to imply that Valentine's

7 I I9I2, in Valentine's later (I9I8) recollection ( $A M C S U$, I.2, p. 33).

72 Ov. Fast. 4.4I9-620; the phrases quoted come from vv. 4I9 and 428.

73 See Saunders' note at Ford (2010: 165).

74 And pedantically corrects Valentine's translation: “"It ought, you know,” Tietjens said $[\ldots]$ "to be 'Kisses mingled with sad tears' [...]". 
knowledge of Latin is less secure than it seems, but when she herself recalls these events in I9I 8 , she remembers how 'they had spouted Tibullus one to another in moonlit mist' (AMCSU, I.2, p. 33$) \cdot{ }^{75}$ This poem, too, of course, reflects back on the situation: on this night-journey, where Christopher and Valentine begin to feel their strong attraction to each other, love and death enter their minds; Valentine's later recollections, on the day when the War is to end and she will be reunited with Christopher, home in on the previous line, Alebis et arsuro positum me, Delia, lecto ('you will weep for me, Delia, laid on a couch that is to burn') ${ }^{76}$ the words suggesting Tietjens' death and, in lecto, the destruction also of a marriage-bed. ${ }^{77}$

Valentine's competence in Latin, for which we have not only Tietjens' repeated testimony and her own but also that of the headmistress at the school where she comes to teach (not Latin but) physical education (AMCSU, I.3, p. 47), is of special significance in the light both of McKechnie's inability to translate Tietjens' sonnet and the sterility evident in his Virgilian tags, and of Valentine's portrayal as 'in many ways a prototypical feminist ${ }^{78}$ - a suffragette, a woman 'of Advanced Views. And a Latinist. ...' (so characterized in the final volume, Last Post, by the son of Christopher and Sylvia, now himself a Cambridge undergraduate: $L P$, I.3, p. 6o), a woman with '[a]n earning capacity' (thus the headmistress: $A M C S U$, I.3, p. 48), a woman prepared to flout social convention by living in an adulterous relationship with the man she loves. Valentine thus embodies change and female possibility at a time when the male prerogatives of war and politics have brought Europe to collapsing point. ${ }^{79}$ In line with this, her mastery of Latin, which came to her not as it had come to Tietjens and McKechnie, drummed in at school and the great universities, but as a living language from her father's lips, represents a striking challenge to the powerful association of Classics both with class privilege ${ }^{80}$ and, more specifically,

75 The interpretative uncertainty is compounded by Ford's own misattribution, in an essay of 1935, of Tibullus I.I.59-62 (with 59 quoted) to Catullus (Ford 2002: 306). I am indebted to Paul Skinner for drawing this to my attention.

76 AMCSU, I.2, p. 36 ; positum is omitted in the quotation, a further suggestion that failure of memory may affect Valentine as it affects others (cf. p. 45I above, with n. 70).

77 The variable temporal perspective generates differing implications: as the reader looks back to I9I2, it is the risk to Tietjens' life in the War that gains prominence; from the viewpoint of November 1918, with Tietjens safely returned and about to be reunited with Valentine, the effective end of his marriage to Sylvia comes into focus.

78 Haslam's note at Ford (201 ib: 50).

79 The Stoppard television adaptation underscores this reading by having Valentine defend Marie Stopes' Married Love as reading for schoolgirls (Stoppard 2012: 292-3). It should be noted, however, that there are aspects to Valentine that pull against the predominant modern, radical characterization, especially in Last Post; on this ambivalence see Brasme (20I4, esp. I74-80; 20I5: I39-4I).

80 In terms of social class, Valentine is not easily pigeonholed (for a taste of the complexity, see $S D N$, II.5, p. 334: 'Valentine Wannop [...] downright, healthy middle-class-or perhaps upper middle-class - for the Wannops were, if impoverished, yet of ancient 
with men - an association strongly evident (but also undermined) in the work of Woolf, in characters such as Ridley Ambrose in The Voyage Out, Augustus Carmichael in To the Lighthouse, Neville in The Waves, Edward Pargiter in The Years, and, most relevant of all, Jacob Flanders in Jacob's Room, where, as we have seen, Classics is closely linked with war and death. At the same time, whereas, before the War, Valentine reflects on the Cambridge career she might have had, on Armistice Day she rejects the intellectual life for herself, wishing rather 'to lie in a hammock beside a blue, tideless sea and think about Tibullus' ( $A M C S U, \mathrm{I} .3, \mathrm{p} .57)$ - which, in the context, we might very well see as a rejection both of war (one thinks particularly of poem I.Io) and of the uses to which male Classics has been put.

In the work of Woolf and Ford that, in quite different ways, reflects on the Great War, Classics, then, can be seen to possess similar (and multiple) significations. Associated with a world of outdated structures, values, and beliefs, swathed in fantasy and illusion, ossified and voided of meaning, as in the game played by McKechnie and Tietjens (a game that cannot be concluded or won), it yet continued to thrive in different guises, drawing on its power as a universal, historically embedded but leaping beyond (to use Ford's phrase) the 'crack across the table of History' ( $A M C S U$, I. I, p. I7), finding a new place in a culture that had no choice but to embrace change. For the fact was that for writers such as Woolf and Ford, while the cultural critique demanded by the modernism of the post-War years implied the re-evaluation of Classics, Classics itself afforded a precision tool for that critique, and emerged renewed. Then, as many times since, Classics proved adaptive. It does not possess the fixity of the lovely things in the British Museum, and - as we have become sharply aware - it is in this capacity for transformation, this instability, that its stability and strength lie. ${ }^{8 \mathrm{I}}$

\section{Acknowledgements}

For permission to quote from the letters of Johannes Basson to Ulrich von Wilamowitz-Moellendorff I wish to thank the Niedersächsische Staats- und Universitätsbibliothek Göttingen and in particular Dr Johannes Mangei, as well as Professor William M. Calder III, who first made me aware of the existence of the letters. Howard Booth, Leah Flack, Elizabeth Pender, Paul Skinner, and Elizabeth Vandiver all kindly read and offered valuable comments on a draft of this article; welcome help of different kinds was provided by Quentin Broughall, Charlie Kerrigan, Heinz-Günther Nesselrath, Jacobus van der Riet, Johan Thom, and Arnd Witte. I am exceedingly grateful to all, as to participants at the conferences on 'Classics and Classicists in the First World War' (Leeds, 2014) and 'The Poetics

family!'); it is, however, significant that after her father's death she works for a time in domestic service, as a 'slavey' (see esp. $S D N$, I.5, pp. I03-4).

8I For an excellent sketch of the contested and changing cultural status and the regenerative literary dynamic of Classics across the twentieth century, with the First World War as a key reference-point, see Healy (I990). 
of War' (London, 20I5), to audience-members and my fellow-speakers in the panel on 'Refractions of the Great War: Classical Receptions in English Literature, I918-1929' at the Classical Association Annual Conference held in Nottingham in 20I4, and to audiences in Durham and Maynooth.

\section{References}

M. Arkin, 'Hirschhorn, Friedrich Heinrich', in C. J. Beyers (ed.), Dictionary of South African Biography, IV (Durban: Butterworth, I981), pp. 237-8.

J. Basson, De Cephala et Planude syllogisque minoribus (Göttingen: Dieterich, I9I7).

B. Benedict, 'International Exhibitions and National Identity', Anthropology Today 7, no. 3 (I99 I), pp. 5-9.

W. Benjamin, 'The Storyteller: Reflections on the Works of Nikolai Leskov', in Benjamin, Illuminations, ed. by H. Arendt, tr. by H. Zohn (London: Fontana, I973 [I936]), pp. 83-Io9.

I. Brasme, 'Articulations of Femininity in Parade's End', in A. Chantler and R. Hawkes (eds), Ford Madox Ford's Parade's End: The First World War, Culture, and Modernity, International Ford Madox Ford Studies, I3 (Amsterdam: Rodopi, 2014), pp. I73-85.

- 'Parade's End', in A. Chantler and R. Hawkes (eds), An Introduction to Ford Madox Ford (Farnham: Ashgate, 2015), pp. 135-48.

P. Brendon, The Decline and Fall of the British Empire I78I-I997 (London: Vintage, 2008 [2007]).

C. Clark, The Sleepwalkers: How Europe Went to War in I9I4 (London: Penguin, 2013 [2012]).

T. S. Eliot, 'Tradition and the Individual Talent', in Eliot, Selected Essays, 3 rd enlarged edn (London: Faber and Faber, 195I [1919]), pp. I3-22.

S. Evangelista, British Aestheticism and Ancient Greece: Hellenism, Reception, Gods in Exile (Basingstoke: Palgrave Macmillan, 2009).

J. Fairhall, Fames Foyce and the Question of History (Cambridge: Cambridge University Press, I993).

L. C. Flack, 'I922's "UnUlyssean" Ulysses: Modern Visions and Revisions of the Homeric Nostos', in

H. Gardner and S. Murnaghan (eds), Odyssean Identities in Modern Cultures: The Fourney Home (Columbus, OH: Ohio State University Press, 20I4), pp. I33-49.

F. M. Ford, 'Hands off the Arts', in M. Saunders and R. Stang (eds), Ford, Critical Essays (Manchester: Carcanet Press, 2002 [1935]), pp. 300-8.

— Some Do Not ..., ed. by M. Saunders (Parade's End, I; Manchester: Carcanet Press, 20 Iо [1924]).

$\longrightarrow$, No More Parades, ed. by J. Wiesenfarth (Parade's End, II; Manchester: Carcanet Press, 20 г Ia [1925]).

—, A Man Could Stand Up-ed. by S. Haslam (Parade's End, III; Manchester: Carcanet Press, 20 I Ib [I926]).

- Last Post, ed. by P. Skinner (Parade's End, IV; Manchester: Carcanet Press, 20 I Ic [I928]).

R. Fowler, “'On Not Knowing Greek”: The Classics and the Woman of Letters', Classical Fournal 78, no. 4 (I983), pp. 337-49.

_ - 'Moments and Metamorphoses: Virginia Woolf's Greece', Comparative Literature 5I (I999), pp. 21 $7-42$.

C. Froula, Virginia Woolf and the Bloomsbury Avant-Garde: War, Civilization, Modernity (New York: Columbia University Press, 2005).

P. Fussell, The Great War and Modern Memory (New York: Oxford University Press, 2013 [1975]).

A. Gasiorek, 'Ford and Politics', in A. Chantler and R. Hawkes (eds), An Introduction to Ford Madox Ford (Farnham: Ashgate, 2015), pp. I 89-200.

L. Gordon, Virginia Woolf: A Writer's Life, rev. edn (London: Virago, 20o6).

E. Gregory, H.D. and Hellenism: Classic Lines, Cambridge Studies in American Literature and Culture, I I I (Cambridge: Cambridge University Press, I997).

H.D. [Hilda Doolittle], Bid Me to Live (London: Virago, I984 [1960]).

T. Healy, 'Literature and the Classics', in M. Coyle, P. Garside, M. Kelsall, and J. Peck (eds), Encyclopedia of Literature and Criticism (London: Routledge, I990), pp. 964-75.

F. M. Hueffer [Ford], On Heaven and Poems Written on Active Service (London: John Lane, i9r8). 
M. Hussey (ed.), Virginia Woolf and War: Fiction, Reality, and Myth (Syracuse, NY: Syracuse University Press, I99I).

S. Hynes, A War Imagined: The First World War and English Culture (London: Bodley Head, I99o).

V. Kolocotroni, J. Goldman, and O. Taxidou (eds), Modernism: An Anthology of Sources and Documents (Chicago: University of Chicago Press, 1998).

T. Koulouris, Hellenism and Loss in the Work of Virginia Woolf (Farnham: Ashgate, 20I I).

C. Lamos, 'Virginia Woolf's Greek Lessons', in L. Doan and J. Garrity (eds), Sapphic Modernities: Sexuality, Women and National Culture (New York: Palgrave Macmillan, 2006), pp. I49-64.

S. Latham and G. Rogers, Modernism: Evolution of an Idea (London: Bloomsbury, 20I 5).

H. Lee, The Novels of Virginia Woolf (London: Methuen, I977).

—, Virginia Woolf (London: Vintage, I997 [1996]).

K. L. Levenback, Virginia Woolf and the Great War (Syracuse, NY: Syracuse University Press, 1999). P. Lewis, The Cambridge Introduction to Modernism (Cambridge: Cambridge University Press, 2007). M. MacKay, Modernism, War, and Violence (London: Bloomsbury, 20I7).

D. E. McCoskey and M. J. Corbett, 'Virginia Woolf, Richard Jebb, and Sophocles' Antigone', in K. Ormand (ed.), A Companion to Sophocles (Chichester: Wiley-Blackwell, 20 I2), pp. 462-76.

A. Mirkovic, 'Imperial History in Pictures: Goetze Murals in the United Kingdom's Foreign Office', World History Connected I I, no. I (20I4) http://worldhistoryconnected.press.illinois.edu/I I.I/ forum_mirkovic.html [last accessed I2 February 20I8].

M. North, Novelty: A History of the Nem (Chicago: University of Chicago Press, 2013).

W. Owen, The Complete Poems and Fragments, ed. by J. Stallworthy, 2 vols (London: Chatto \& Windus, I983).

J. B. Priestley, Margin Released: A Writer's Reminiscences and Reflections (London: Mercury Books, I966 [1962]).

K. Puschmann, Der Homberger Hermann Wilhelm Malcomess (I848-I92I): Ein deutscher Pionier in Südafrika, Homberger Hefte, 7 (Homberg: Zweigverein Homberg an der Efze des Vereins für hessische Geschichte und Landeskunde, I970).

J. Raphaely, 'Nothing but Gibberish and Shibboleths?: The Compulsory Greek Debates, I870-I919', in C. Stray (ed.), Classics in Igth and 2oth Century Cambridge: Curriculum, Culture and Community, Cambridge Philological Society Supplementary Volume 24 (Cambridge: Cambridge Philological Society, I999), pp. 7I-94.

L. P. Romero Mariscal, Virginia Woolfy el helenismo, I897-I925, Novatores, 33 (Valencia: Institució Alfons el Magnànim, 2012).

M. Saunders, Ford Madox Ford: A Dual Life, 2 vols (Oxford: Oxford University Press, I996).

F. Smuts, 'Die Klassieke op Stellenbosch', Nemsletter, Department of Greek and Latin, University of Stellenbosch I I, no. 3 (i 966 ), pp. Io-53, 87.

A. Spiropoulou, “'On Not Knowing Greek”: Virginia Woolf's Spatial Critique of Authority', Interdisciplinary Literary Studies 4, no. I (2002), pp. I-I9.

R. E. Spoo, "Nestor" and the Nightmare: The Presence of the Great War in Ulysses', Tmentieth Century Literature 32 (1986), pp. I37-54.

R. Stevenson, Literature and the Great War I9I4-I9I8 (Oxford: Oxford University Press, 20I3).

T. Stoppard, Parade's End: Based on the Novel by Ford Madox Ford (London: Faber and Faber, 20 I2).

C. Stray, Classics Transformed: Schools, Universities, and Society in England, I830-1960 (Oxford: Oxford University Press, I998).

E. Vandiver, Stand in the Trench, Achilles: Classical Receptions in British Poetry of the Great War (Oxford: Oxford University Press, 2010).

M. H. Whitworth, Virginia Woolf (Oxford: Oxford University Press, 2005).

C. A. P. Willsdon, Mural Painting in Britain I840-I940: Image and Meaning (Oxford: Oxford University Press, 2000).

A. N. Wilson, After the Victorians (London: Arrow, 2006 [2005]).

V. Woolf, 'On Not Knowing Greek', in Woolf, The Common Reader (London: Hogarth Press, 1925), pp. 39-59.

, The Letters of Virginia Woolf, ed. by N. Nicolson and J. Trautmann, 6 vols (London: Hogarth Press, 1975-80). 
—, To the Lighthouse, ed. by S. Dick (Oxford: Blackwell, I992 [1927]).

—, Jacob's Room, ed. by E. L. Bishop (Malden, MA: Blackwell, 2004 [i 922]).

—, 'The Leaning Tower', in S. N. Clarke (ed.), The Essays of Virginia Woolf, VI (London: Hogarth Press, 20 I [ [1940]), pp. 259-83.

—, Mrs. Dalloway, ed. by A. E. Fernald (Cambridge: Cambridge University Press, 2015 [1925]). 